\title{
Obituary: Helmut Gottwald
}

\author{
Uwe Schmitt · Gerald Koch · Hans-Georg Richter
}

Published online: 25 January 2009

(C) Springer-Verlag 2009

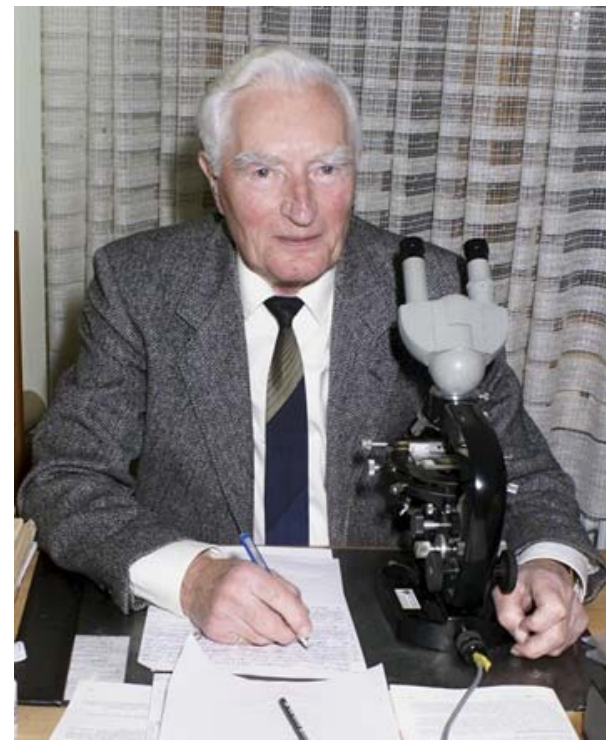

Helmut Gottwald was born in Cosel/Upper Silesia on 5 November 1918 and died in Reinbek near Hamburg on 7 October 2008 after a prolonged illness, shortly before celebrating his 90th birthday, and 25 years after retiring from official duties. Surviving World War II, Helmut Gottwald first worked as an apprenticed carpenter from 1945 to 1947 and then studied at the University of Hamburg. From 1951 to 1955 he taught at a vocational school in Hamburg before he joined the staff of the Federal Research Centre for Forestry and Forest Products (now Johann Heinrich von Thünen-Institute, vTI) in 1957 and started his remarkable career as a scientist in the field of systematic and applied wood anatomy with emphasis on wood properties and utilization. One year later he succeeded Eberhard Schmidt as head of the wood 
anatomy department. Besides the daily routine work in wood identification, Helmut Gottwald's main scientific interest focused on applied wood science, systematic studies of important woody plant families, and the expansion of the Hamburg wood collection. Under his responsibility, the collection developed into an internationally recognised, highly valuable scientific collection with 18,000 specimens backed by some 40,000 microscopic slides. Numerous publications and technical leaflets about the most important trade timbers as well as innumerable expert opinions document his activities. He also developed a keen interest in the anatomy and identification of fossil woods, a topic he never really found the time to follow until his retirement in 1983 .

Helmut Gottwald was a well-known wood scientist in Germany and achieved an international reputation through his comprehensive publications and study visits to subtropical and tropical countries. Along with various short-term missions, he visited for longer periods Myanmar, Thailand, Zaire, Papua New Guinea and the Amazon region of Bolivia and Brazil. He joined the International Association of Wood Anatomists (IAWA) in 1963 and served as member on the Committee which produced the IAWA list of Microscopic Features for Hardwood Identification, published in 1987.

For more than 25 years, Helmut Gottwald served as an inspiring lecturer at the University of Hamburg, introducing many generations of Wood Science and Technology students to the art of macroscopic wood identification and wood quality assessment, taking much pride in the 'high grades' he was awarded by his students. He also took responsibility in supervising M.Sc. and Ph.D. wood science students with great success. In 1958, he published his book on commercial timbers, a standard textbook which sold out completely within 1 year of publication. The book is still heavily used by wood science students and the wood industry and trade community.

The Academy elected Helmut Gottwald as Fellow in 1983, the year in which he retired from his duties at the Hamburg Research Centre, and which was also the starting point for his second career as a paleobotanist dedicating most of his time to the study of fossil woods. This work resulted in the publication of more than 20 highly regarded papers and made him one of the foremost scientists in this field.

Helmut Gottwald was a stimulating and loyal colleague who always shared his knowledge and vast experience with all who wanted to learn from him. The international wood science community has lost one of its prominent members and we have lost a good friend. 